\title{
Albanon
}

Revistë kulturore

\section{Mbi një variant empatik të baladës së murimit}

Skënder Karriqi

Ideja se patjetër në Luginën e Shkumbinit flinte diku një variant i Baladës së murimit, kishte filluar të na ngacmonte prej kohësh. Për ne ishte paradoksale që kjo luginë, ku kalonte lumi, i cili ndante Shqipërinë dhe shqiptarët në gegë e toskë, pikërisht, aty pra, ku gjithsesi, fillonte njëfarë dizintegrimi gjuhësor dhe etnografik i shqiptarëve, të mos mbartej Balada e sakrificës. Përndryshe, Lugina e Shkumbinit konsiderohet nga arkeologët edhe si Lugina e Egnatia-s. Në këtë kuptim, ajo sipas prof. Neritan Cekës, ka qenë një kondicioner ku kanë fryrë dhe janë gërshetuar "erërat" kulturore të Lindjes dhe Perëndimit.

Nisur nga bindja jonë, se balada duhet të flinte diku, në një nga këto ditë pranvere me shira të gjatë, bashkë me mësuesin e anlgishtes, z. Lavdim Alliu, vajtëm në Qukës-Shkumbin, atje ku kishim identifikuar më parë gojëdhënën për "Gurin e Qumështit”. Në fakt ishte fjala për një këmbë ure, ku sipas gojëdhënës, pikonte qumështi i nuses prej shekujsh e murosur. Atje, gratë e sëmura nga gjiri shkonin për të gjetur shpëtim, pasi pinin disa pika nga ai qumësht shërues. Matanë lumit, pikërisht atje, ku fillon fshati tjetër, QukësSkënderbe, në një shtëpi dykatëshe me oborr të sistemuar me mure të thata guri, flinte Balada e murimit në variantin shkumbinas.

U takuam me xha Zyhdi Kushtën, i cili u gëzua kur na pa. Kishte kohë që konaku i tij nuk priste njerëz. Djemtë i kishte në emigrim dhe gjithë ai oborr i gjerë "popullohej” nga pak njerëz: ai, bashkëshortja, nusja e djalit të vogël dhe djali i saj 3-4 vjeçar. Pasi u thanë fjalët e para që shërbejnë për t’u njohur më mirë, ndërkohë që e kishim pirë nga një kafe, e pyetëm xha Zyhdiun për Baladën dhe ai na e tha siç e dinte: 
1- O more imzot,

Pse më qan me lot?

2- Më ka rën' çekiçi

Në themel përposht'.

3- Hani buk' e hani drek'

Un' çekiçin e nxjerr vet.

4- Un' hyra të nxjerr çekiçin,

Im kunat filloi tertipin...!

Intonacioni i mbyllur, i përfunduar vulos edhe fundin e kësaj balade. Krahasuar me variante të tjera lokale, kombëtare e mbarëkombëtare, bie në sy menjëherë shkurtësia e saj: duket sikur ajo është e paemër dhe si e tillë, pa histori e parahistori, një materie fjalësh, që edhe pse të sistemuara, qëndrojnë si në ajër, pa mbështetje. Kur e pyetëm xha Zyhdiun, morëm vesh se një variant i gjatë i kësaj balade interpretohej midis këndimit dhe recitimit, deri aty nga vitet '70 prej rapsodit Zyber Haxhia. Që në gjallje të tij, kur donin të stigmatizonin një bisedë apo këngë të stërzgjatur, njerëzit dhe veçanërisht të rinjtë, përdornin shprehjen: "Na e bëre muhabetin si kënga e xha Zyberit". Pra varianti i gjatë, pikërisht për gjatësinë e tij, nuk preferohej më. Stili radiofonik, publicistik apo qoftë edhe ai telegrafik, me sa duket kishin kultivuar (apo ishin në kultivim e sipër) shije të reja. Në këtë kontekst, varianti i gjatë i kësaj baladë u reduktua, u çlirua nga historia dhe parahistoria, apo nga shenja të tilla identifikuese, të cilat e lidhnin atë me personazhe të veçantë: fjala vjen me një Rozafë, një Tanë, një Tringë apo një Aishe. E çliruar prej këtyre shenjave, ajo mbeti thjesht "Kënga e nuses".

Nga ana tjetër, përsëri krahasuar me variante të tjera lokale, kombëtare e mbarëkombëtare, varianti i Baladës për urën mbi lumin Shkumbin në Qukës (Librazhd), dallon për një vetë të parë të veçantë. Edhe në variantet e tjera, veta e parë është e pranishme, por ajo vjen si një vetë dialogjike e rrëfyer nga një rrëfyes i gjithëdijshëm i cili, kur është fjala për këtë vetë (të parë), ka për referencë kohën kur e sakrifikuara është e gjallë apo në agoni e sipër, siç është rasti i mallkimit të saj në një prej varianteve si më poshtë:

Ashtu siç dridhem un' nën mur,

Ashtu u dridhtë edhe kjo ur'!

Po kështu, edhe varianti shkumbinas i Qukësit (Librazhd), në distikët 1, 2, 3, veta e parë, është e tillë, që nuk e kalon kufirin e vdekjes, madje nuk e takon fare atë (thënë ndryshe, nuk e kalon pikën zero). Por këta distikë 


\section{Albanon}

\section{Revistë kulturore}

dialogiikë, edhe pse të reduktuar, të çliruar nga historia dhe parahistoria, të çliruar gjithashtu edhe nga shenjat e rrëfimtarit të gjithdijshëm, në tërësinë e këtij varianti, janë në vetvete shenja të variantit të dikurshëm, prej të cilit kanë dalë. Pikërisht, për këtë arsye, në këtë variant shkumbinas kemi ndjesinë e dy kohëve: të kohës kur zhvillohet veta e parë dialogjike në distikët 1, 2, 3 dhe të kohës së vetërrëfimit të së sakrifikuarës në distikun 4, si më poshtë:

Un' hyra të nxjerr çekiçin,

Im kunat filloi tertipin!

Pikërisht këtu, te distiku 4 qëndron edhe e veçanta e vetës së parë në variantin shkumbinas. Ajo, siç u tha më lart, është një vetë e parë e vetërrëfyer e cila në këtë rast, e kalon kufirin e vdekjes (thënë më thjesht, e sakrifikuara flet pas vdekjes). Në qoftë se ky distik nuk shihet në këtë këndvështrim, kjo do të thotë se sakrifica nuk ka ndodhur, çka është katërcipërisht në kundërshtim me logjikën e Baladës. Në asnjë nga variantet e tjera lokale, kombëtare e mbarëkombëtare, nuk gjejmë qoftë edhe një varg apo shenjë ku e sakrifikuara të flasë pas vdekjes. Përballë këtij fakti të vjen ideja se distiku 4 (pra i fundit) i variantit shkumbinas, dallohet si një distik empatik, me sa duket i përftuar nga jeta aktive që ka bërë Balada përgjatë Luginës së Shkumbinit, sidomos aty ku ajo u gjend dhe këndohet sot e kësaj dite nga gratë dhe nuset e luginës; në Qukës (Librazhd).

Duke përjetuar thellë dramën e sakrificës, vetidentifikimi i grave dhe nuseve të luginës duhet të ketë arritur në shkallën empatike, aq sa gjithsecila prej atyre që, sipas rastit e këndonte këtë Baladë, e ndiente veten heroinë të sakrifikuar. Pikërisht ky përjetim empatik, reflekton gjuhësisht vetën e parë si vetë përjetimi, në të cilën padyshim spikat edhe ndjenja e protagonizmit heroik. Sigurisht, është fjala për një heroizëm të heshtur që shumë-shumë e gjen shprehjen nëpërmjet këngës, e cila në ambiente konservatore, doemos ishte një këngë e ndrojtur, e kufizuar përgjithësisht në rrethin e grave dhe nuseve.

Varianti shkumbinas i Baladës së murimit, duke përkuar në një mjedis ku për shekuj me radhë, sidomos nëpërmjet Egnatia-s kanë fryrë dhe janë kryqëzuar "erërat" kulturore të lindjes dhe të perëndimit, ka bërë pra një jetë aktive në vatrat e banorëve në të dyja anët e Shkumbinit. Pikërisht, për këtë arsye ai vjen deri në ditët e sotme si një variant empatik, i reduktuar në masën e një kënge polifonike dyzërashe dhe me shenja origjinale në raport me variantet dhe invariantet e tjera. Si i tillë, ky variant shkumbinas meriton vëmendje në perspektivën e studimeve të fushës. 